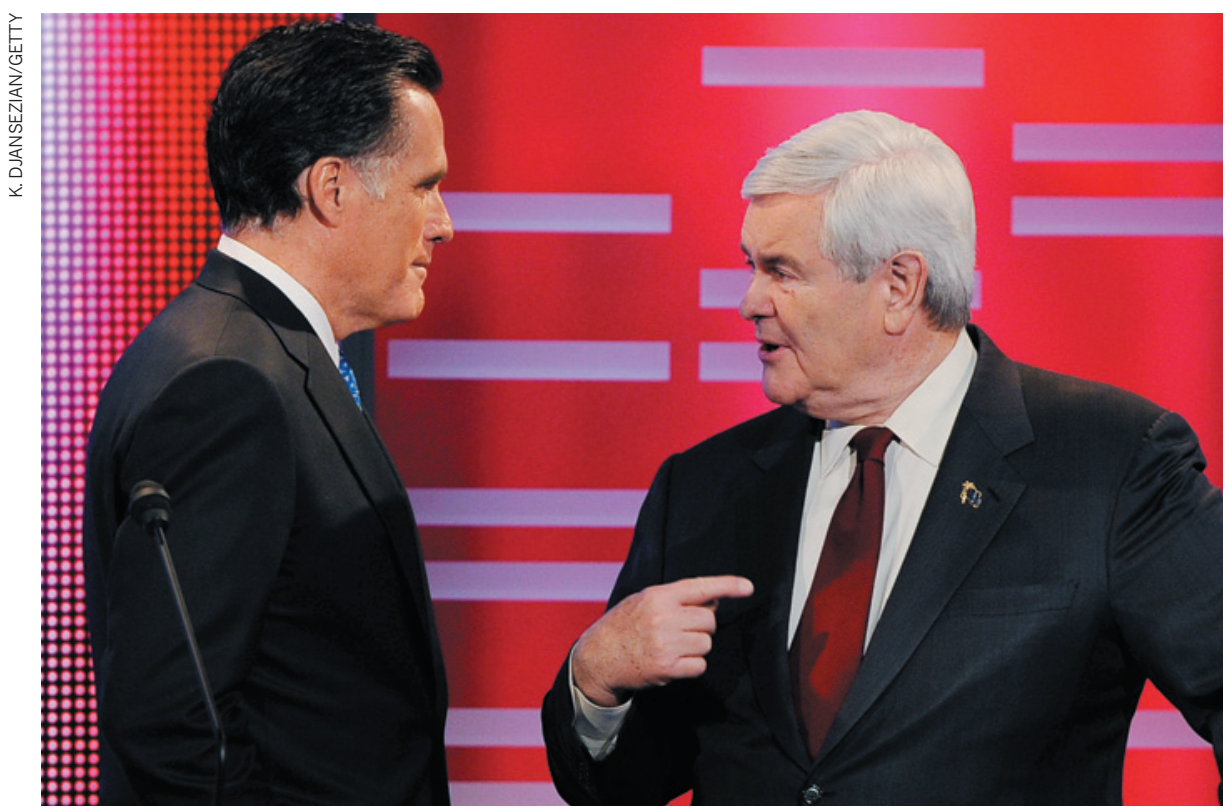

Mitt Romney (left) and Newt Gingrich have shifted their views on the threat posed by climate change.

US ELECTION

\title{
Candidates play to the right on science
}

\section{Rivals for the Republican nomination laud research but take a hard line on embryonic stem cells and climate.}

\section{BY SUSAN YOUNG}

$\mathrm{U}$ S presidential elections do not tend to revolve around science. But thanks to the latest twist in the race for the Republican candidacy, the unusual topic of mining the Moon looks set to be up for discussion. Lunar resources and the space programme in general are popular themes with former US House speaker Newt Gingrich. Following his decisive victory over the Republican frontrunner, former Massachusetts governor Mitt Romney, in the South Carolina primary on 21 January, Gingrich - whose fortunes have zigzagged during the campaign - is back in the media spotlight.

Romney and Gingrich now dominate an unsettled contest. Both are taking staunchly conservative positions on controversial science issues: they are against regulating carbon emissions and oppose embryonic stem-cell research. Yet both have held more moderate views in the past. And, with concern growing about unemployment and international competition (see page 420), the state of US research and its role as an economic driver could have more resonance than usual in this year's presidential race.
"The public supports science strongly", says Mary Woolley, president of the medical-science advocacy group Research!America, based in Alexandria, Virginia. "They can connect the dots between science and better jobs for themselves, their children, their grandchildren. They don't want to be part of a country that's not making progress in science at the level we used to."

Last November, the group sent a list of research-oriented questions to all candidates, including US President Barack Obama, against whom the winner of the Republican contest will face off later this year. So far, only Gingrich and Obama have responded. In keeping with Republican ideology, Gingrich credits the US private sector as the key driver of technical innovation and success. But his tone is urgent. "We are on the cusp of an explosion of new science that will create new opportunities in health, agriculture, energy, and materials technology," he writes. "We must move quickly and decisively so we will be the creators of this innovation, not just the recipients of it." Now, with the race moving on to the Florida primary on 31 January, Gingrich has promised to deliver a visionary speech on the US space programme, in the tradition of Democratic president John F. Kennedy. Yet, on stem cells, Gingrich leans firmly 
to the right, mindful that many social conservatives in the United States equate research on human embryos with abortion. In 2009, Obama lifted a ban imposed by former Republican president George W. Bush that limited federal funding for human embryonic stemcell research to just a handful of existing cell lines. By contrast, Gingrich says he would "oppose at every turn any process of destroying embryos". That could mean a freeze on the approval of new lines, or possibly an end to federal funding for such work altogether.

Romney's history on the issue is more complex. As a candidate for governor in 2002, he voiced general support for stem-cell science. But, once in office, he vetoed a 2005 bill that allowed cloning to create human embryonic stem cells for research. Romney was overruled by the state's legislature, but the following year his administration set down regulations that could have criminalized the work of scientists using human embryonic stem cells. However, no scientists were prosecuted under the regulations, and the bill was amended when the next governor took over.

The positions that Romney and Gingrich now espouse suggest that if either were to be

in the White House with a Congress similar to today's, US stem-cell policy would take a hard right turn. "It would be very likely that there would be a reduction or elimination of funding for embryonic stem-cell research", says Alta Charo, a professor of law and bioethics at the University of Wisconsin-Madison.

"Any time a scientist stands up in a public forum and says climate change is real and we need to do something about it, there are immediate repercussions."

grounds, from a region: several northeastern states banded together to reduce emissions.

Gingrich's turn on climate has been even more abrupt. In 2008, he teamed up with Democrat and then House speaker Nancy Pelosi in a television advert promoting political action on climate change. He has since been chastised for this by conservative commentators. Gingrich now says he regrets the ad and, in recent weeks, has further distanced himself from his proactive former stance. After he was criticized on rightwing talk radio for involving Katharine Hayhoe, a climate scientist at Texas Tech University in Lubbock, in a book project on environment entrepreneurship, Gingrich said he would drop Hayhoe's chapter from the book. Hayhoe supports the idea that human activity is driving climate change. "Any time a scientist stands up in a public forum and says climate change is real and we need to do something about it, there are immediate repercussions," Hayhoe says.

Yet whoever becomes the Republican candidate - and whoever ultimately becomes president - these disputes may not mean much for the support of science as a whole. Since the cold war, both Republican and Democratic administrations have a steady record of support for basic science. And with the US electorate focused on the economy and unemployment, it seems likely that if science is discussed at all in this year's campaign it will be in the context of jobs and competitiveness issues on which all candidates, no matter what their ideology, see a need for action. . for gene-therapy push

\section{Genethon relaunches itself as a force for translational medicine.}

\section{BY ALISON ABBOTT}

$\mathrm{T}$ The French biotechnology institute Genethon is perhaps best known for its unusual funding source - annual television appeals - and for its mapping of the human genome in the early $1990 \mathrm{~s}$ (I. Chumakov et al. Nature 359, 380-387; 1992). Now, after spending years in the scientific doldrums, it plans to become known as the European centre that can speed up the process of getting gene therapy for rare genetic disorders into routine clinical practice.

Scientific director Fulvio Mavilio, a molecular biologist who took office earlier this month, has a mandate to sharpen the research profile of the institute, which employs 180 scientific staff at its base just outside Paris. One of his main strategies is to create international clinical networks for gene therapy around Genethon. The institute should become particularly attractive to international partners later this year, when it opens what will be the world's biggest plant for producing large volumes of clinical-grade viral vectors - used to transfer therapeutic genes into the cells of patients.

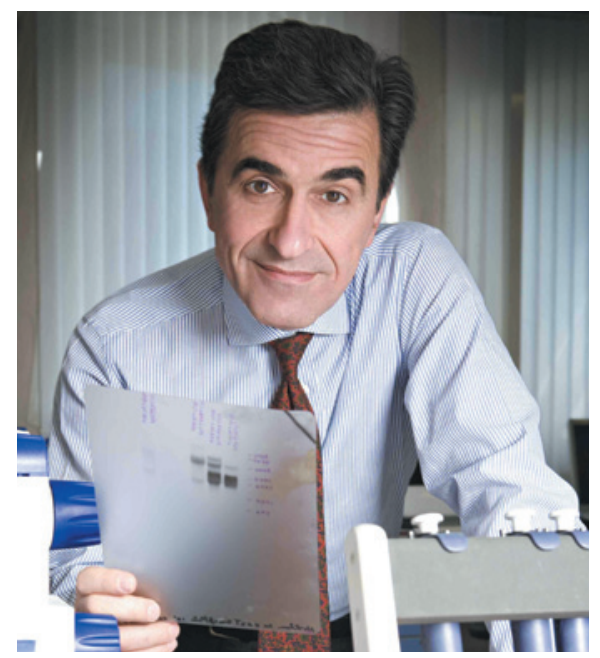

Fulvio Mavilio is Genethon's new scientific director.
"Getting vectors is a bottleneck for us," says Adrian Thrasher, director of the gene-therapy programme at University College London's Institute of Child Health, and a Genethon collaborator. "Genethon's new strategy is realistic."

The first gene-therapy trials involved a handful of children in Italy and France who had rare and fatal immunodeficiency disorders, and showed that healthy genes could be transferred stably into patients to reverse their symptoms.

The early successes spawned a period of hype that came to an abrupt end with the 1999 death of Jesse Gelsinger, a teenager in the United States who had a profound immune reaction to his gene therapy, as well as the emergence of cancers in some immunedeficient children who had been treated. Progress has been slow and cautious ever since. More than a thousand proof-of-principle clinical studies have been done around the world (see 'Gene promise'), and dozens have shown positive results, but as yet no form of gene 